\title{
Journal of Threatened Taxa
}

Building evidence for conservation globally

www.threatenedtaxa.org

ISSN 0974-7907 (Online) | ISSN 0974-7893 (Print)

\section{COMMUNICATION}

\section{DOES THE SIZE OF THE BUTTERFLY ENHANCE DETECTION? FACTORS INFLUENCING BUTTERFLY DETECTION IN SPECIES INVENTORY SURVEYS}

Anju Velayudhan, Ashokkumar Mohanarangan, George Chandy \& S. Biju

26 March 2021 | Vol. 13 | No. 3 | Pages: 17950-17962

DOI: 10.11609/jott.6596.13.3.17950-17962
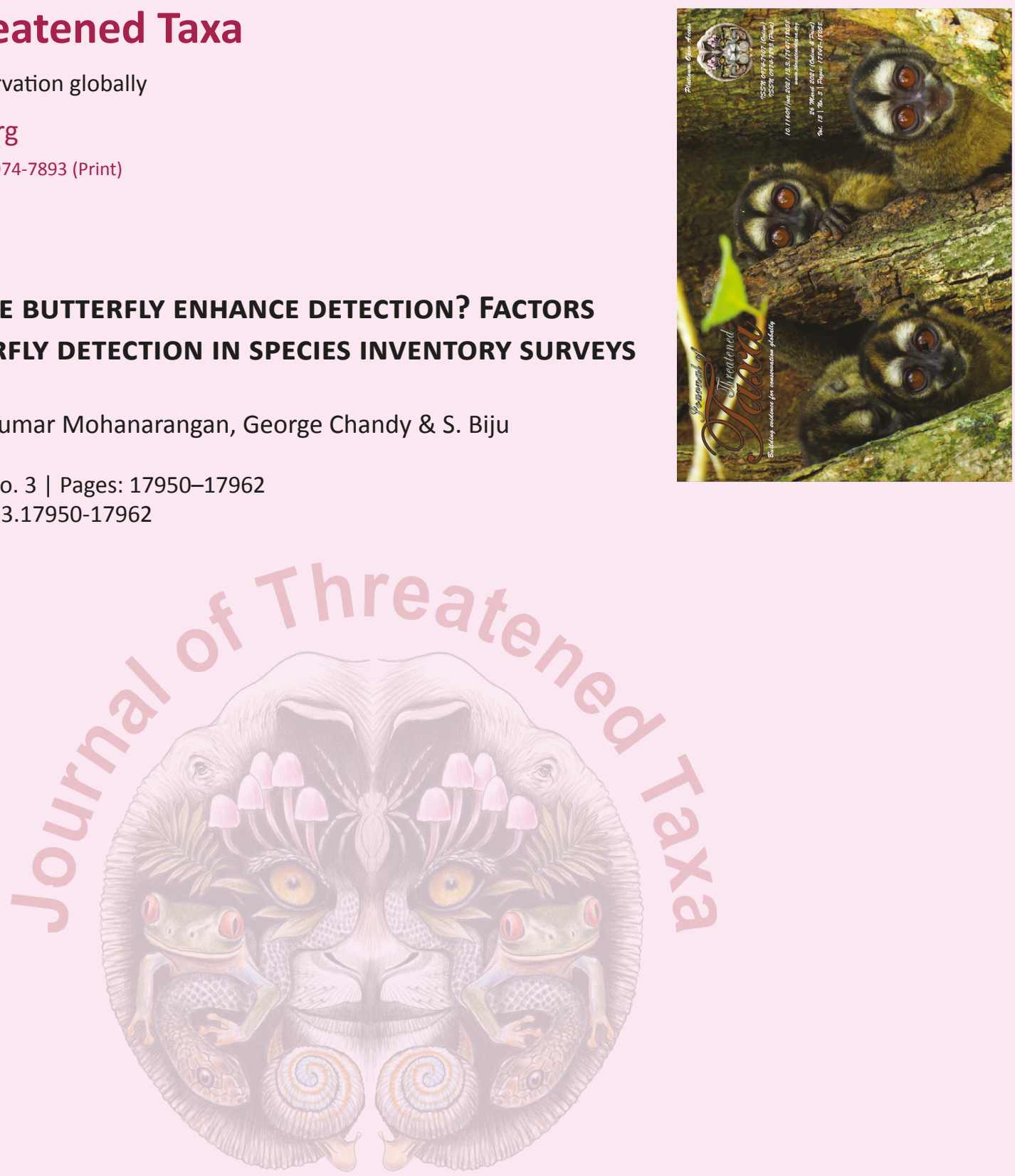

For Focus, Scope, Aims, Policies, and Guidelines visit https://threatenedtaxa.org/index.php/JoTT/about/editorialPolicies\#custom-0 For Article Submission Guidelines, visit https://threatenedtaxa.org/index.php/JoTT/about/submissions\#onlineSubmissions For Policies against Scientific Misconduct, visit https://threatenedtaxa.org/index.php/JoTT/about/editorialPolicies\#custom-2 For reprints, contact <ravi@threatenedtaxa.org>

The opinions expressed by the authors do not reflect the views of the Journal of Threatened Taxa, Wildlife Information Liaison Development Society, Zoo Outreach Organization, or any of the partners. The journal, the publisher, the host, and the partners are not responsible for the accuracy of the political boundaries shown in the maps by the authors.

\section{Publisher \& Host}
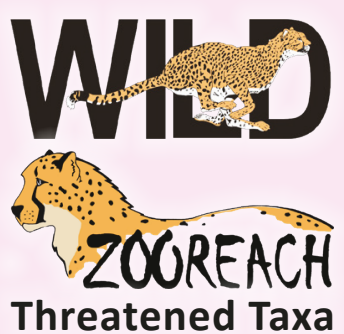

\section{Member




\title{
Does the size of the butterfly enhance detection? Factors influencing butterfly detection in species inventory surveys
}

\author{
Anju Velayudhan ${ }^{1}\left(\mathbb{D}\right.$, Ashokkumar Mohanarangan ${ }^{2}$ (D), George Chandy ${ }^{3}$ (D) \& S. Biju ${ }^{4}$ (i) \\ ${ }^{1,2,3}$ Center for Wildlife Studies, Kerala Veterinary and Animal Sciences University, Pookode, Wayanad, Kerala 673576, India. \\ ${ }^{4}$ Department of Livestock Production and Management, College of Veterinary and Animal Sciences, Mannuthy, Kerala 680651, India. \\ ${ }^{1}$ anjuvanju95@gmail.com, ${ }^{2}$ vimalashok7@gmail.com (corresponding author), ${ }^{3}$ chandy@kvasu.ac.in, ${ }^{4}$ bijus@kvasu.ac.in
}

\begin{abstract}
Butterfly species' abundance and factors influencing butterfly detection in Chimmony Wildlife Sanctuary, Kerala was studied from April to June 2018. The survey was carried out on 15 tracks of 2-km lengths surveyed two times resulting in the sampling effort of $60 \mathrm{~km}$. A total of 141 species of butterflies belonging to two orders, six families and 103 genera were observed during the study, of which 15 species were recorded as endemic. The majority of butterfly species belonged to the families Nymphalidae and Lycanidae. The size of butterflies varies significantly among families with the largest butterflies recorded in Papilionidae and Nymphalidae and the smallest butterflies from Hesperidae and Lycanidae. The factors that determine butterfly detection during the count was determined using multiple regression. The number of detections had a linear relation with abundance, size, and activities of the butterflies. The model was highly significant and explained $86.9 \%$ of the variation in the detection of butterflies $(F=407.8 ; d f=3 ; p<0.000)$. Abundance had a primary influence on detection followed by the size and activities of the butterflies. Further studies on relative detectability of different species of butterflies in the diversity and abundance estimation would help in refining methods of assessment of butterflies.
\end{abstract}

Keywords: Abundance, Chimmony Wildlife Sanctuary, Hesperidae, Lepidoptera, Lycanidae, Nymphalidae

Editor: B.A. Daniel, Zoo Outreach Organisation, Coimbatore, India.

Date of publication: 26 March 2021 (online \& print)

Citation: Velayudhan, A., A. Mohanarangan, G. Chandy \& S. Biju (2021). Does the size of the butterfly enhance detection? Factors influencing butterfly detection in species inventory surveys. Journal of Threatened Taxa 13(3): 17950-17962. https://doi.org/10.11609/jott.6596.13.3.17950-17962

Copyright: (c) Velayudhan et al. 2021. Creative Commons Attribution 4.0 International License. JoTT allows unrestricted use, reproduction, and distribution of this article in any medium by providing adequate credit to the author(s) and the source of publication.

Funding: None.

Competing interests: The authors declare no competing interests.

Author details: ANJU VELAYUDHAN (AV) has completed Post-Graduation in Wildlife Studies from KVASU-Centre for Wildlife Studies, Pookode, Wayanad. She is passionate about butterflies and she has carried out studies on butterfly species inventory surveys and the life cycle of butterflies. Presently she has been preparing for higher studies. Ashokкumar Mohanarangan (MA) has completed his Masters and Doctoral degree in Wildlife biology, from AVC College, Tamil Nadu. He is passionate about wild animal population ecology and conservation. He is working as Teaching Assistant at KVASU-CWS. GEORGE CHANDY (GC) has completed masters and PhD, in Veterinary Sciences. He is the Course Director of KVASU-Centre for Wildlife Studies and he is passionate about Wildlife Conservation and Tribal Welfare. BIJU S. (BS) has completed masters and PhD, in Veterinary Sciences. He is working as an Assistant Professor in the Department of Livestock Production and Management.

Author contribution: MA developed the concept, formulated hypothesis and did data analysis. AV did the field data collection, conceived the idea and carried out the preliminary analysis. GC and BS supervised the work and preparation of the final manuscript.

Acknowledgements: The authors are thankful to the chief wildlife warden for granting permission to conduct the research study in the Chimmony Wildlife Sanctuary (WL10-13885/2017 dated 23.03.2018). We thank the wildlife warden and other field staff for their support at the time of the survey.

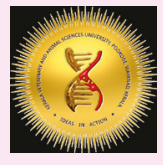




\section{INTRODUCTION}

Butterflies are universally popular among all fauna. They are very beautiful and come in various sizes, shapes, and colours. Different patterns on their body enhance their aesthetic value (Gupta \& Majumdar 2012). The Western Ghats can be classified into three biogeographical parts based on the status and distribution of butterflies. They are the southern Western Ghats, central Western Ghats and the northern Western Ghats (Gaonkar 1996). Because of high levels of species endemism, the Western Ghats is listed under 34 global biodiversity hotspots. The region is prominent among all other biodiversity hotspots (Myers et al. 2000). The butterfly fauna of the Western Ghats consists of 346 species of butterflies under six families (Bhakre \& Ogle 2018).

Most of the inventory surveys were carried out by sampling through forest paths and trails without any information on the sample area (Sudheendrakumar et al. 2000; Sreekumar \& Balakrishnan 2001; Aneesh et al. 2013), hence it was not possible to estimate population density. The systematic surveys using fixed width transect or using pollard walk (Isaac et al. 2011) helps to estimate the population density of butterflies with the same sampling effort by recording additional information on length and width of the area sampled. It is essential to determine the different factors that determine the detection probability. Species-wise differences in the detection probability of butterflies were reported in the studies carried out in the United Kingdom (Isaac et al. 2011).

The family Nymphalidae is the most dominant family with a high number of species. A detailed diversity study of butterflies in Chimmony Wildlife Sanctuary (CWS) has not been done yet. Previous studies reported 24 species of butterflies in the study area (George 2012). We have investigated butterfly species size and abundance influence on the detection of butterflies in inventory surveys at CWS.

\section{METHODS}

\section{Study area}

The study was conducted in Chimmony Wildlife Sanctuary, which spreads geographically within $76.417 \mathrm{~N}$ and $10.402 \mathrm{E}$ and $76.560 \mathrm{~N}$ and $10.483 \mathrm{E}$ in Thrissur District of Kerala State (George 2012). The sanctuary was established in the year 1984. The sanctuary consists of parts of Kodassery Reserve with an extent of $85.07 \mathrm{~km}^{2}$.
It is bounded by Nelliampathy Reserve Forest on the east, Peechi-Vazhani Wildlife Sanctuary on the northwest, and Sholayar Reserve Forest on the south (Fig. 1). The mean annual rainfall is $3,130 \mathrm{~mm}$. The sanctuary has a tropical humid climate, with three distinct seasons, dry season (December-March) followed by the south-west monsoon (April-July), and north-east monsoon (AugustNovember). Temperature varies from $38.5^{\circ} \mathrm{C}$ to $15.6^{\circ} \mathrm{C}$ during different seasons. The minimum temperature falls below $15.6^{\circ} \mathrm{C}$ during December. The area is also vulnerable to forest fires during the dry season. The sanctuary has more than 250 streams and six man-made waterholes. Diverse vegetation and favourable climatic conditions in the sanctuary could support many species of butterflies.

\section{Butterfly abundance estimation}

Butterfly species abundance was estimated using fixed-width transect method in CWS from April 2018 to August 2018. Totally, 15 strip transects of $2 \mathrm{~km}$ were selected along paths with 2-m width on either side of the transect and sampled twice that resulted in the sampling effort of $60 \mathrm{~km}$. The surveys were conducted between $09.30 \mathrm{~h}$ and $13.30 \mathrm{~h}$ when the butterflies were most active. The butterflies observed in the field were photographed for further clarification and identification. Butterflies were identified using field guides (Kunte 2006; Palot 2015; Kehimkar 2016; Bhakre \& Ogale 2018) and specialists were consulted in case of uncertainty in the identification of species. The butterflies were photographed using a Nikon 3100 DSLR camera with 18-50mm and 70-300 mm lens. The butterfly survey routes were marked with GPS (Fig.1).

Statistical analysis was performed by using Windowsbased statistical package Microsoft Excel, PAST (Hammer et al. 2001) and SPSS. The diversity indices such as Simpson and Shannon-Wiener index of butterfly species from each habitat were analysed with the help of software PAST. Butterfly size difference among different families was tested using one-way analysis of variance (one-way ANOVA). The factors that determine the detection of butterflies, such as abundance, activities (0-resting; 1-foraging, flying, mud puddling, etc), size of butterflies were tested using multiple regression. Both response and independent variables were log-transformed due to positive skewness of data. Linearity was examined by plotting the relationship between the response variable (number of detections) and each predictor variable (abundance and size) using Lowess plot. To investigate multicollinearity between the environmental covariates, a correlation analysis was conducted before using 


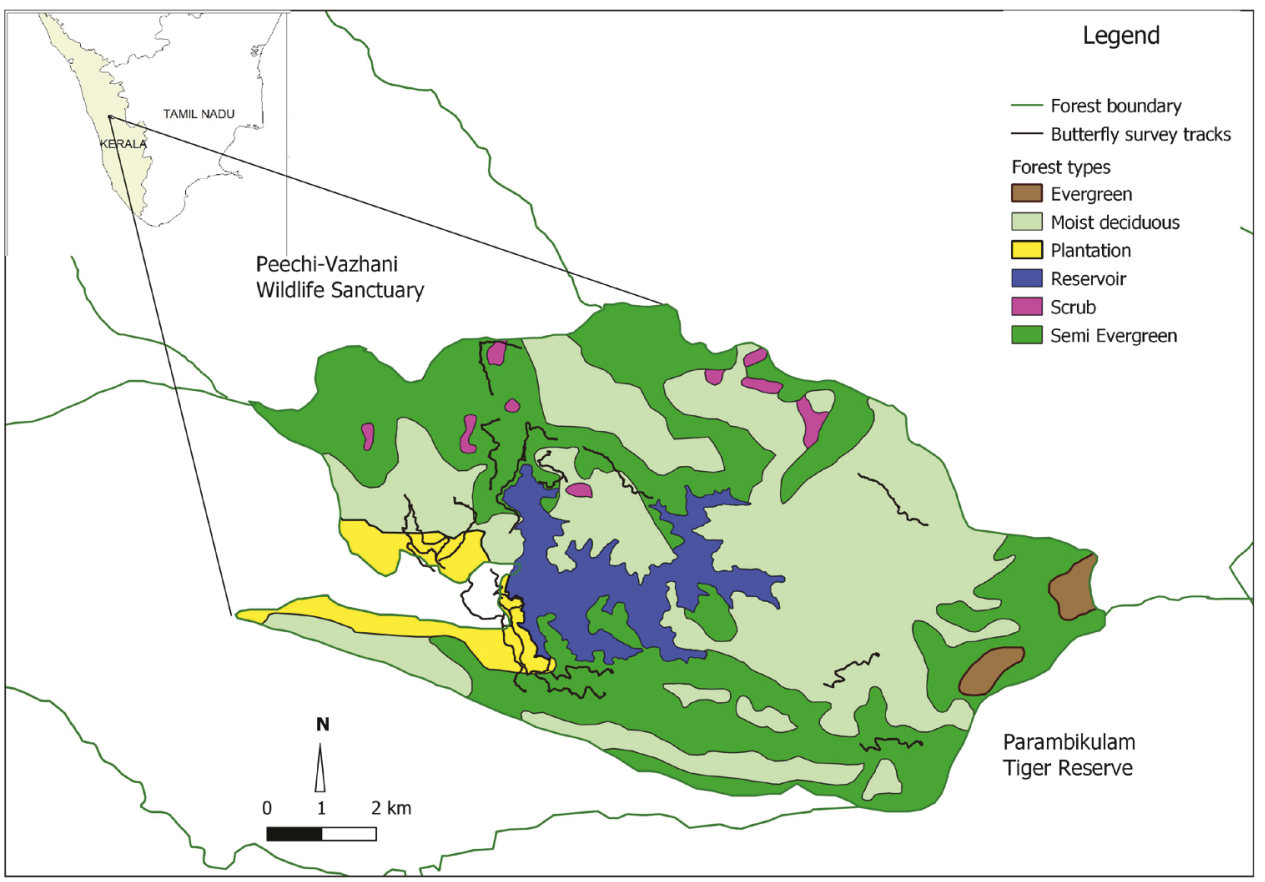

Figure 1. Chimmony Wildlife Sanctuary and butterfly survey routes in the study area. multiple regressions to assess the relationships between the response variable and predictor variables, thereby providing valid parameter estimates and $p$ values. The data were analyzed using SPSS Statistics 21 (IBM SPSS Inc., Chicago, Illinois, USA).

\section{RESULTS}

Totally, 141 butterfly species were documented in CWS from April to June 2020. Butterfly species composition varied among different families, with Nymphalidae and Lycanidae constituting 62\%. Families such as Hesperidae, Papilionidae, and Pieridae were constituted $16.3 \%, 12.8 \%$, and $8.5 \%$, respectively. Only one species (Double-banded Judy) was recorded in the family of Riodinidae. Thus there is significant variation in the number of species recorded among different families $\left(X^{2}=67.3 ; d f=5 ; p<0.01\right)$. The majority of butterfly species belong to Nymphalidae and Lycanidae in Chimmony Wildlife Sanctuary.

In total, 15 species are found to be endemic to the Western Ghats region (Table 1). Butterfly species such as Indian Ace, Shiva Sunbeam, Blue Oakleaf, Danaid Eggfly, Gladeye Bushbrown, Malabar Tree Nymph, Tailed Palmfly, Tamil Catseye, and Southern Birdwing are endemic species (Images 1-45). There are four species of butterflies such as Orchid Tit, Malabar Banded Swallowtail, Crimson Rose, and Danaid Eggfly listed in the Schedule I of the Indian Wildlife Protection Act (1972). In total there are 20 species of butterflies that are catalogued in the Schedules of IWPA and provide protection to the butterflies. Common Lineblue is the most abundant butterfly followed by Common Crow and Common Emigrant in CWS. There were more than 100 individuals of all these butterflies that were recorded in the study area. There were 42 species that were recorded only once during the time of the survey.

\section{Factors that determine detection of butterflies}

The size of butterflies varies among families with the largest sized butterflies recorded from Papilionidae and Nymphalidae $(102.8 \pm 23 \mathrm{~mm}$ and $70.1 \pm 20.1 \mathrm{~mm})$. Hesperidae $(37.5 \mathrm{~mm})$ and Lycanidae $(30.6 \mathrm{~mm})$ are the smallest-sized butterflies. Pieridae and Riodinidae are the medium-sized butterflies $(57.7 \mathrm{~mm}$ and $45 \mathrm{~mm}$, respectively). There is a significant difference in the size of butterflies among different families $(F=118.20$; $d f=5$; $\mathrm{p}<0.001$ ).

The relationship between the number of detection, abundance, and size of butterflies were tested using multiple regression. The number of detection had linear relation with abundance, size, and activities of the butterflies. The model was highly significant and explained $86.9 \%$ variation in the detection of butterflies $(F=407.76 ; d f=3 ; p<0.00 ;$ Table 2). All the three predictors had positive abundance and size positively influenced number of detections. From the standardized 
Table 1. Butterfly species and their abundance (data sorted in descending order) recorded in Chimmony Wildlife Sanctuary.

\begin{tabular}{|c|c|c|c|c|c|c|}
\hline & \multirow{2}{*}{ Family/ Common name } & \multirow{2}{*}{ Species } & \multirow{2}{*}{$\begin{array}{l}\text { Abundance } \\
\text { of butterflies }\end{array}$} & \multicolumn{3}{|c|}{ IWPA -Schedule } \\
\hline & & & & 1 & $1, \mathrm{II}$ & II,IV \\
\hline & Hesperidae & & & & & \\
\hline 1 & Demon sp. & Notocrypta sp. & 10 & & & \\
\hline 2 & Dusky Partwing & Psolos fuligo & 8 & & & \\
\hline 3 & Water Snow Flat & Tagiades litigiosa & 7 & & & \\
\hline 4 & Chestnut Bob & lambrix salsala luteipalpis & 6 & & & \\
\hline 5 & Golden Angle & Caprona ransonnettii & 6 & & & \\
\hline 6 & Common Banded Demon & Notocrypta paralysos mangla & 5 & & & \\
\hline 7 & Chestnut Angle & Odontoptilum angulata & 4 & & & \\
\hline 8 & Common Spotted Flat & Celaenorrhinus leucocera & 3 & & & \\
\hline 9 & Bevan's Swift & Pseudoborbo bevani & 1 & & & \\
\hline 10 & Brown Awl & Badamia exclamationis & 1 & & & \\
\hline 11 & Common Red Eye & Matapa aria & 1 & & & \\
\hline 12 & Common Small Flat & Sarangesa dasahara dasahara & 1 & & & \\
\hline 13 & Dark Palm-dart & Telicota bambusae bambusae & 1 & & & \\
\hline 14 & Grass Demon & Udaspes folus & 1 & & & \\
\hline 15 & Indian Ace** & Halpe homolea hindu & 1 & & & 1 \\
\hline 16 & Indian Dartlet & Oriens goloides & 1 & & & \\
\hline 17 & Pygmy Scrub Hopper & Aeromachus pygmaeus & 1 & & & \\
\hline 18 & Restricted Demon & Notocrypta curvifascia & 1 & & & \\
\hline 19 & Spotted Small Flat & Sarangesa purendra hopkinsi & 1 & & & \\
\hline 20 & Suffused Snow Flat & Tagiades gana silvia & 1 & & & \\
\hline 21 & Tamil Grass Dart & Taractrocera ceramas & 1 & & & \\
\hline 22 & Tricoloured Pied Flat & Coladenia indrani indra & 1 & & & \\
\hline \multirow[t]{2}{*}{23} & Wax Dart & Cupitha purreea & 1 & & & \\
\hline & Lycaenidae & & & & & \\
\hline 24 & Common Lineblue & Prosotas nora & 240 & & & \\
\hline 25 & Tailless Lineblue & Prosotas dubiosa & 60 & & & \\
\hline 26 & Tiny Grass Blue & Zizula hylax & 44 & & & \\
\hline 27 & Common Pierrot & Castalius rosimon & 29 & & & \\
\hline 28 & Quaker & Neopithecops zalmora & 29 & & & \\
\hline 29 & Lesser Grass Blue & Zizina otis & 26 & & & \\
\hline 30 & Angled Pierrot & Caleta decidia & 21 & & & \\
\hline 31 & Monkey Puzzle & Rathinda amor & 15 & & & \\
\hline 32 & Common Imperial & Cheritra freja butleri & 12 & & & \\
\hline 33 & Yamfly & Loxura atymnus atymnus & 12 & & & \\
\hline 34 & Plains Cupid & Chilades pandava & 10 & & & \\
\hline 35 & Fluffy Tit & Zeltus amasa & 9 & & & \\
\hline 36 & Common Cerulean & Jamides celeno & 8 & & & \\
\hline 37 & Many-tailed Oakblue & Thaduka multicaudata Kanara & 8 & & & 1 \\
\hline 38 & Metallic Cerulean & Jamides alecto & 8 & & & \\
\hline 39 & Common Hedge Blue & Acytolepis puspa felderi & 5 & & & \\
\hline 40 & Dark Cerulean & Jamides bochus & 5 & & & \\
\hline 41 & Banded Blue Pierrot & Discolampa ethion & 3 & & & \\
\hline
\end{tabular}




\begin{tabular}{|c|c|c|c|c|c|c|}
\hline & \multirow{2}{*}{ Family/ Common name } & \multirow{2}{*}{ Species } & \multirow{2}{*}{$\begin{array}{l}\text { Abundance } \\
\text { of butterflies }\end{array}$} & \multicolumn{3}{|c|}{ IWPA -Schedule } \\
\hline & & & & I & $\mathrm{I}, \mathrm{II}$ & II,IV \\
\hline 42 & Dark Pierrot & Tarucus ananda & 3 & & & $1(\mathrm{IV})$ \\
\hline 43 & Gram Blue & Euchrysops cnejus & 3 & & & 1 \\
\hline 44 & Shiva Sunbeam** & Curetis siva & 3 & & & \\
\hline 45 & Dingy Lineblue & Petrelaea dana & 2 & & & \\
\hline 46 & Indian Sunbeam & Curetis thetis & 2 & & & \\
\hline 47 & Large Oakblue & Arhopala amantes & 2 & & & \\
\hline 48 & Apefly & Spalgis epeus & 1 & & & \\
\hline 49 & Common Silverline & Spindasis vulcanus & 1 & & & \\
\hline 50 & Cornelian & Deudorix epijarbas & 1 & & & \\
\hline 51 & Forget-me-not & Catochrysops Strabo & 1 & & & \\
\hline 52 & Indigo Flash & Rapala varuna & 1 & & & 1 \\
\hline 53 & Lime Blue & Chilades lajus & 1 & & & 1 \\
\hline 54 & Malayan & Megisba malaya & 1 & & & \\
\hline 55 & Orchid Tit & Chliaria othona & 1 & 1 & & \\
\hline 56 & Plain Hedge Blue & Celastrina lavendularis lavendularis & 1 & & & \\
\hline 57 & Pointed Lineblue & Ionolyce helicon viola & 1 & & & 1 \\
\hline 58 & Redspot & Zesius chrysomallus & 1 & & & \\
\hline \multirow[t]{2}{*}{59} & Slate Flash & Rapala manea & 1 & & & \\
\hline & Nymphalidae & & & & & \\
\hline 60 & Common Crow & Euploea core & 168 & & & \\
\hline 61 & Chocolate Pansy & Junonia iphita & 71 & & & \\
\hline 62 & Tamil Yeoman & Cirrochroa thais & 46 & & & \\
\hline 63 & Clipper & Parthenos Sy/via & 45 & & & 1 \\
\hline 64 & Common Four-ring & Ypthima huebneri & 45 & & & \\
\hline 65 & Common Castor & Ariadne merione & 24 & & & \\
\hline 66 & Rustic & Cupha erymanthis & 21 & & & \\
\hline 67 & Bushbrown Sp. & Mycalesis sp. & 18 & & & \\
\hline 68 & Common Evening Brown & Melanitis leda & 18 & & & \\
\hline 69 & Great Eggfly & Hypolimnas bolina & 13 & & & \\
\hline 70 & Striped Tiger & Danaus genutia & 12 & & & \\
\hline 71 & Blue Tiger & Tirumala limniace & 10 & & & \\
\hline 72 & Plain Tiger & Danaus chrysippus & 10 & & & \\
\hline 73 & Tamil Lacewing** & Cethosia nietneri & 10 & & & \\
\hline 74 & Angled Castor & Ariadne Ariadne & 9 & & & \\
\hline 75 & Blue Oakleaf** & Kallima horsfieldii & 8 & & & \\
\hline 76 & Common Nawab & Polyura athamas & 8 & & & \\
\hline 77 & Dark Blue Tiger & Tirumala septentrionis & 8 & & & \\
\hline 78 & Common Sailer & Neptis hylas & 7 & & & \\
\hline 79 & Cruiser & Vindula erota & 7 & & & \\
\hline 80 & Glassy Tiger & Parantica aglea & 7 & & & \\
\hline 81 & Lemon Pansy & Junonia lemonias & 7 & & & \\
\hline 82 & Autumn Leaf & Doleschallia bisaltide & 6 & & & 1 \\
\hline 83 & Extra Lascar & Pantoporia sandaka & 6 & & & \\
\hline 84 & Tailed Palmfly** & Elymnia caudata & 5 & & & \\
\hline
\end{tabular}




\begin{tabular}{|c|c|c|c|c|c|c|}
\hline & \multirow{2}{*}{ Family/ Common name } & \multirow{2}{*}{ Species } & \multirow{2}{*}{$\begin{array}{l}\text { Abundance } \\
\text { of butterflies }\end{array}$} & \multicolumn{3}{|c|}{ IWPA -Schedule } \\
\hline & & & & 1 & $\mathrm{I}, \mathrm{II}$ & II,IV \\
\hline 85 & Commander & Moduza procris & 4 & & & \\
\hline 86 & Gladeye Bushbrown** & Mycalesis patnia & 4 & & & \\
\hline 87 & Grey Pansy & Junonia atlites & 4 & & & \\
\hline 88 & Chestnut-streaked Sailer & Neptis jumbah & 3 & & & \\
\hline 89 & Dark Evening Brown & Melanitis phedima & 3 & & & \\
\hline 90 & Dark-branded Bushbrown & Mycalesis mineus & 3 & & & \\
\hline 91 & Grey Count & Tanaecia lepidea & 3 & & & 1 \\
\hline 92 & Yellow Pansy & Junonia hierta & 3 & & & \\
\hline 93 & Black Prince & Rohana parisatis & 2 & & & \\
\hline 94 & Blackvein Sergeant & Athyma ranga & 2 & & & 1 \\
\hline 95 & Common Lascar & Pantoporia hordonia & 2 & & & \\
\hline 96 & Danaid Eggfly** & Hypolimnas misippus & 2 & & 1 & \\
\hline 97 & Medus Bushbrown & Orsotriaena medus & 2 & & & \\
\hline 98 & Tamil Catseye** & Zipaetis saitis & 2 & & & 1 \\
\hline 99 & Black Rajah & Charaxes solon & 1 & & & \\
\hline 100 & Blue Admiral & Kaniska canace & 1 & & & \\
\hline 101 & Brown King Crow & Euploea klugii & 1 & & & \\
\hline 102 & Common Five-ring & Ypthima baldus & 1 & & & \\
\hline 103 & Common Three-ring & Ypthima asterope & 1 & & & \\
\hline 104 & Double-branded Crow & Euploea Sylvester & 1 & & & \\
\hline 105 & Great Evening Brown & Melanitis zitenius & 1 & & & 1 \\
\hline 106 & Malabar Tree Nymph** & Idea malabarica & 1 & & & \\
\hline 107 & Peacock Pansy & Junonia almana & 1 & & & \\
\hline 108 & Plain Tawny Rajah & Charaxes psaphon & 1 & & & \\
\hline 109 & Red-spot Duke & Dophla evelina & 1 & & & 1 \\
\hline \multirow[t]{2}{*}{110} & Tawny Coster & Acraea terpsicore & 1 & & & \\
\hline & Papilionidae & & & & & \\
\hline 111 & Common Mormon & Papilio polytes & 73 & & & \\
\hline 112 & Narrow-banded Bluebottle & Graphium teredon & 65 & & & \\
\hline 113 & Blue Mormon & Papilio polymnestor & 64 & & & \\
\hline 114 & Southern Birdwing** & Troides minos & 20 & & & \\
\hline 115 & Tailed Jay & Graphium Agamemnon & 19 & & & \\
\hline 116 & Common Jay & Graphium doson & 16 & & & \\
\hline 117 & Red Helen & Papilio helenus & 15 & & & \\
\hline 118 & Five-bar Swordtail & Graphium antiphates & 11 & & & \\
\hline 119 & Paris Peacock & Papilio paris & 11 & & & \\
\hline 120 & Malabar Raven** & Papilio dravidarum & 10 & & & \\
\hline 121 & Lime & Papilio demoleus & 5 & & & \\
\hline 122 & Malabar Rose** & Pachliopta pandiyana & 5 & & & \\
\hline 123 & Common Rose & Pachliopta aristolochiae & 4 & & & \\
\hline 124 & Malabar Banded Swallowtail** & Papilio liomedon & 4 & 1 & & \\
\hline 125 & Common Mime & Papilio clytia & 2 & & & \\
\hline 126 & Spot Swordtail & Graphium nomius & 2 & & & \\
\hline 127 & Common Banded Peacock & Papilio crino & 1 & & & \\
\hline
\end{tabular}




\begin{tabular}{|c|c|c|c|c|c|c|}
\hline & \multirow{2}{*}{ Family/ Common name } & \multirow{2}{*}{ Species } & \multirow{2}{*}{$\begin{array}{l}\text { Abundance } \\
\text { of butterflies }\end{array}$} & \multicolumn{3}{|c|}{ IWPA -Schedule } \\
\hline & & & & 1 & $\mathrm{I}, \mathrm{II}$ & II,IV \\
\hline \multirow[t]{2}{*}{128} & Crimson Rose & Pachliopta hector & 1 & 1 & & \\
\hline & Pieridae & & & & & \\
\hline 129 & Common Emigrant & Catopsilia Pomona & 112 & & & \\
\hline 130 & Three-spot Grass Yellow & Eurema blanda & 55 & & & \\
\hline 131 & Common Grass Yellow & Eurema hecabe & 53 & & & \\
\hline 132 & Great Orange Tip & Hebomoia glaucippe & 50 & & & \\
\hline 133 & Nilgiri Grass Yellow** & Eurema nilgiriensis & 28 & & & \\
\hline 134 & Common Wanderer & Pareronia hippia & 24 & & & \\
\hline 135 & Common Albatross & Appias albina & 22 & & & \\
\hline 136 & One-spot Grass Yellow & Eurema andersonii & 18 & & & 1 \\
\hline 137 & Lesser Gull & Cepora nadina & 11 & & & 1 \\
\hline 138 & Mottled Emigrant & Catopsilia pyranthe & 3 & & & \\
\hline 139 & Psyche & Leptosia nina & 3 & & & \\
\hline \multirow[t]{2}{*}{140} & Spotless Grass Yellow & Eurema laeta & 1 & & & \\
\hline & Riodinidae & & & & & \\
\hline 141 & Double-banded Judy & Abisara bifasciata & 3 & & & \\
\hline
\end{tabular}

**-Endemic species

Table 2. Multiple regression to investigate the effect of factors that influence detection of butterflies in Chimmony Wildlife Sanctuary.

\begin{tabular}{|c|c|c|c|c|c|c|c|c|}
\hline Independent Variable & Predictor & Coeffic & SEM & SPRC & $\mathbf{t}$ & p & Model $\left(r^{2}\right)$ & model (p) \\
\hline \multirow{4}{*}{ Number of detections } & (Constant) & -0.476 & 0.185 & & -2.572 & 0.011 & \multirow{4}{*}{0.869} & \multirow{4}{*}{$\begin{array}{c}F=407.76 ; d f=3 ; \\
p<0.00\end{array}$} \\
\hline & Activity & 0.017 & 0.05 & 0.01 & 0.346 & 0.729 & & \\
\hline & Abundance (log) & 0.738 & 0.023 & 0.908 & 32.295 & 0.000 & & \\
\hline & Size of butterflies (log) & 0.190 & 0.048 & 0.108 & 3.978 & 0.000 & & \\
\hline
\end{tabular}

SEM-Standard error of mean | SPRC-Standardized Partial Regression Coefficient

partial regression, it was inferred that abundance $\left(b_{1}=\right.$ 0.74) had the primary influence on the detections, followed by size $\left(b_{2}=0.19\right)$, and activity of the butterflies $\left(b_{3}=0.02\right.$; Fig. 2).

\section{DISCUSSION}

Composition of butterflies varied among different families. A total of 141 species of 1,986 individuals were observed from CWS. Though the study was carried out in a limited period, the number of species reported was higher than earlier reports of the study area (George 2012). The number of species recorded in the study area was more than other protected areas in Kerala; Sudheendrakumar et al. (2000) recorded 124 species at adjacent Parambikulam Tiger Reserve. A total of 71 species from Aralam WS (Sreekumar \& Balakrishnan
2001) have been recorded. The results, however, are not directly comparable outside the protected areas. The number of species recorded in Kerala Agricultural University was 139 species of butterflies (Aneesh et al. 2013). The reason for comparison is the geographical proximity of KAU compass to the study area. The study area is part of the network of protected areas such as Peechi-Vazhani towards north, Sholayar Reserve Forest in the south and Parambikulam Tiger Reserve in the east. The major habitat of the study area is evergreen and moist deciduous forest. Earlier studies recorded higher species diversity and richness in the similar habitats (Sudheendrakumar et al. 2000). Thus, the contiguous forest and evergreen habitat supports higher species diversity and endemism in the study area.

Family Nymphalidae and Lycanidae represented $62 \%$ of the total. Families such as Hesperidae, Papilionidae, and Pieridae were comparatively less. They are, 16.3\%, 

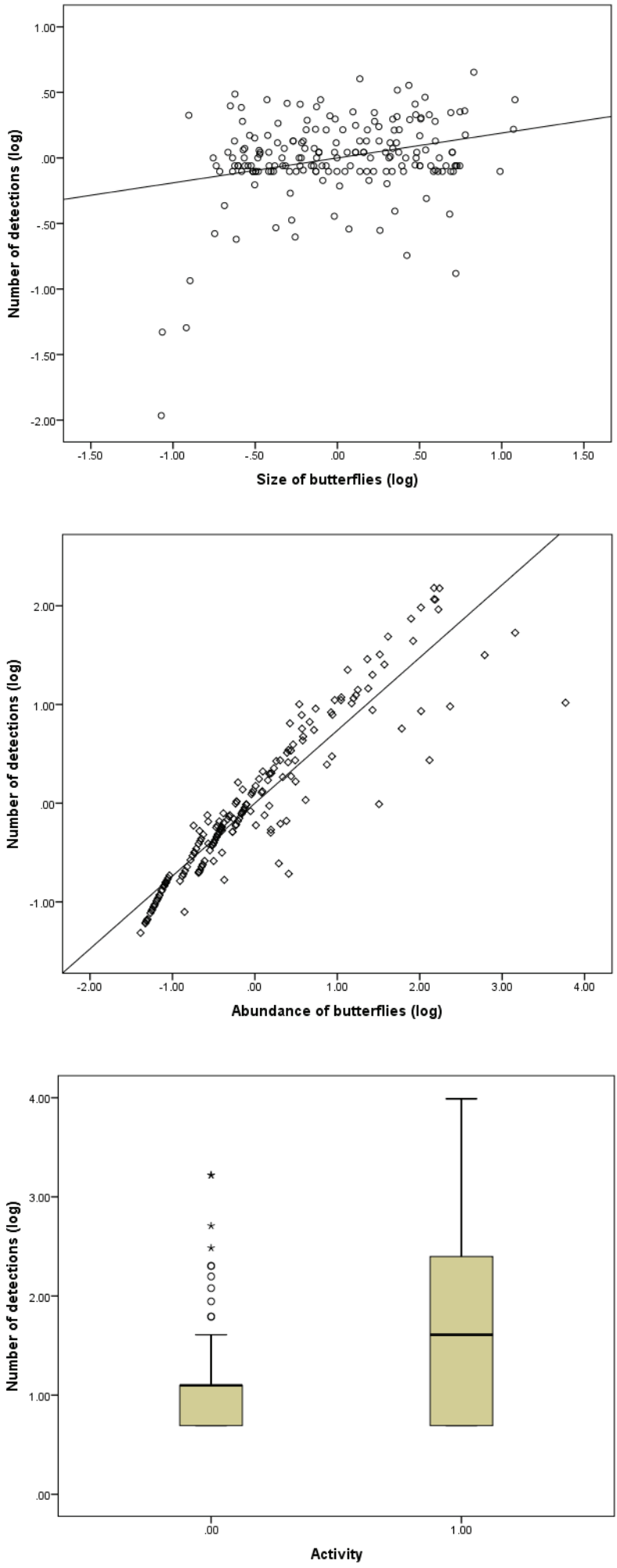

Figure 2. Relation between mean size of butterflies, abundance, activities: 0-Inactive-resting | 1-active-foraging, mud puddling, flying | and number of detections at Chimmony Wildlife Sanctuary.
$12.8 \%$, and $8.5 \%$, respectively. Out of two butterflies in the family Riodinidae of Kerala and Western Ghats, one species (Double-banded Judy) was recorded from the study area during the period of study. There is a significant variation in the species composition among different families. Family Nymphalidae dominated over other families. In almost all the studies conducted in butterflies of Western Ghats (Sudheendrakumar et al. 2000; Sreekumar \& Balakrishnan 2001; Aneesh et al. 2013) Nymphalidae is the family showing the maximum number of species because this is the family representing more number of species in the Western Ghats. The study area harbours $40.7 \%$ of butterfly species of Western Ghats (Bhakre \& Ogle 2018).

In total there are 20 species of butterflies that are listed in various schedules of Indian Wildlife Protection Act (1972) that provide protection to these butterflies. Only $14.2 \%$ of butterflies of recorded species are protected under IWPA. Hence it is important to include all the endemic species in the IWPA and butterflies which are more charismatic, and rapidly declining species need to be listed under the schedules. Common Lineblue is the most abundant butterfly followed by Common Crow and Common Emigrant in CWS. The other species such as Common Mormon, Chocolate Pansy, Narrowbanded Blue Bottle, Blue Mormon, Tailless Lineblue, Three-spot Grass Yellow, and Great Orange Tip were recorded. Similar species composition was recorded in Parambikulam TR (Sudheendrakumar et al. 2000) and Aralam WS (Sreekumar \& Balakrishnan 2001).

\section{Factors that determine detection of butterflies}

The study highlights the differences in the species detection based on size and abundance and importance of differences in detection probability of butterfly species inventory surveys. Butterfly species such as Common Lineblue, Common Crow, Common Emigrant, Common Mormon, Three-spot Grass Yellow, Narrow-banded Bluebottle, and Blue Mormon were more frequently sighted. All these species are conspicuous, larger in size, active flyers, and some species show mud-puddling behaviour as well. This could have resulted in higher abundance and detectability. Studies on butterflies have shown that detection of same species tends to vary according to habitats (Pellet et al. 2012). Further, survey technique could also influence the abundance and density estimation. Thus our preliminary examination on butterfly detectability showed the influence of size, abundance, and activities. The number of detection had a direct relation with the abundance, size, and activities of the butterflies. 


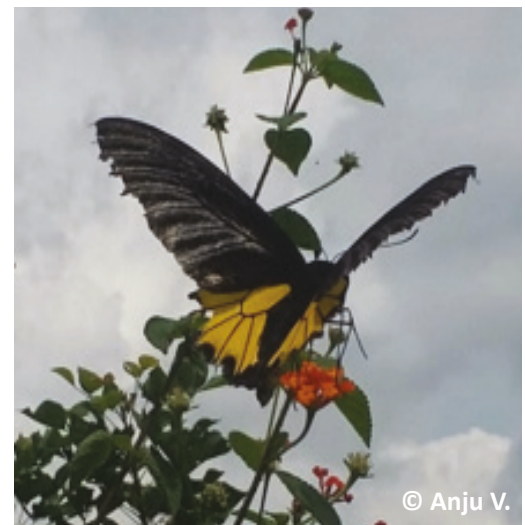

Image 1. Troides minos

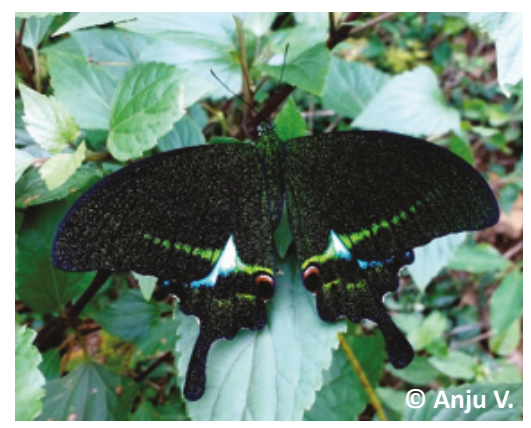

Image 4. Papilio paris

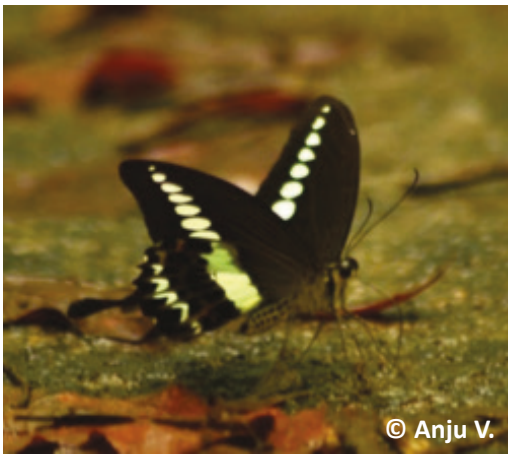

Image 7. Papilio liomedon

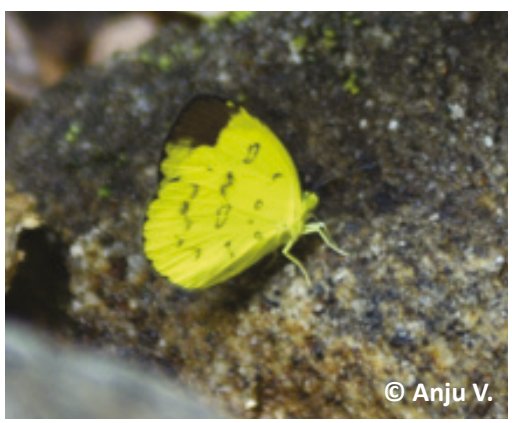

Image 10. Eurema nilgiriensis

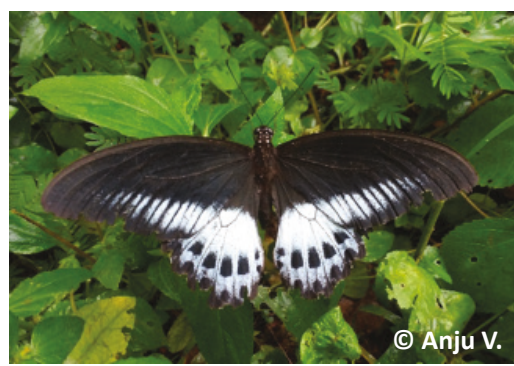

Image 2. Papilio polymnestor

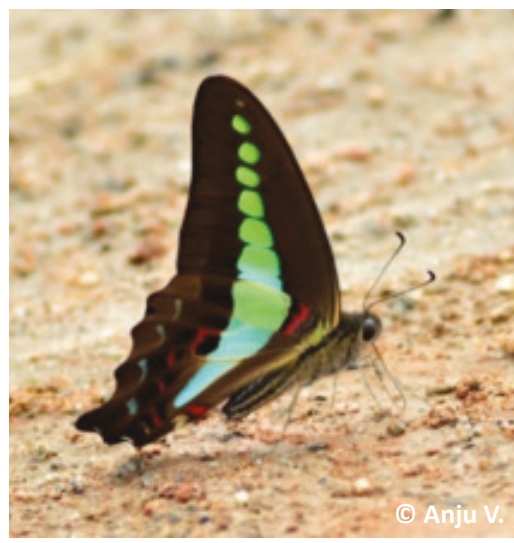

Image 5. Graphium teredon

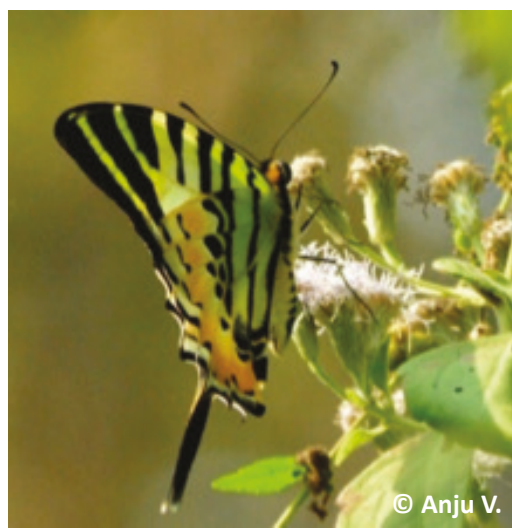

Image 8. Graphium antiphates

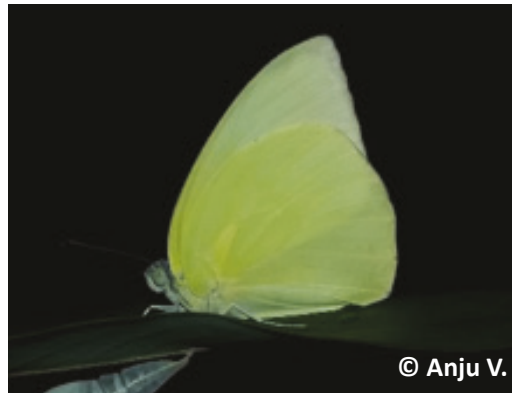

Image 11. Catopsilia pomona

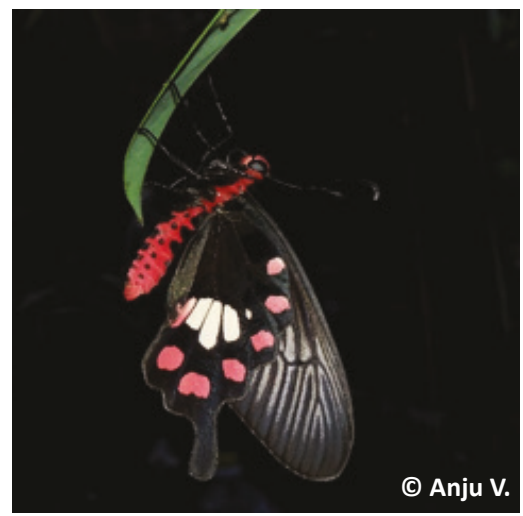

Image 3. Pachliopta aristolochiae

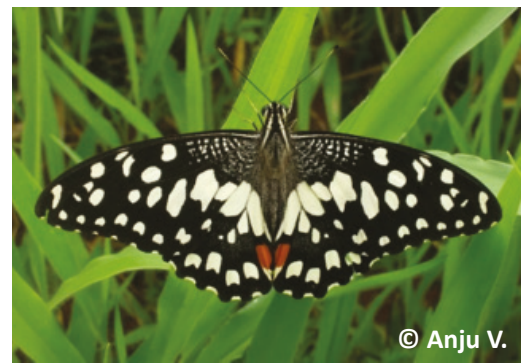

Image 6. Papilio demoleus

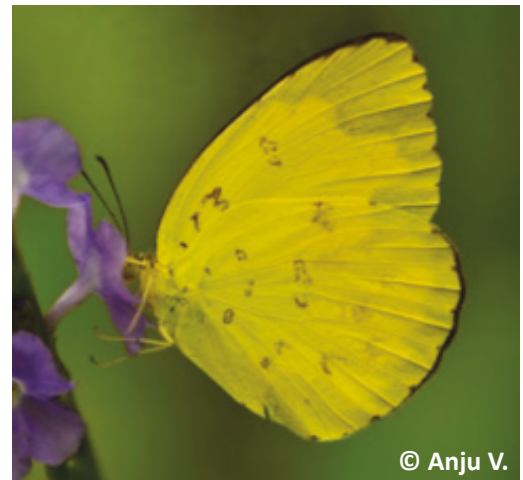

Image 9. Eurema blanda

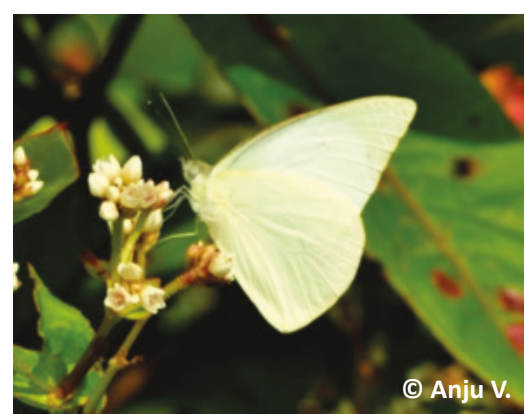

Image 12. Appias albina 


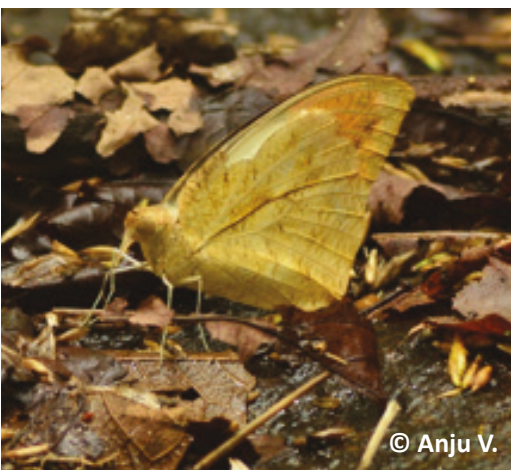

Image 13. Hebomoia glaucippe

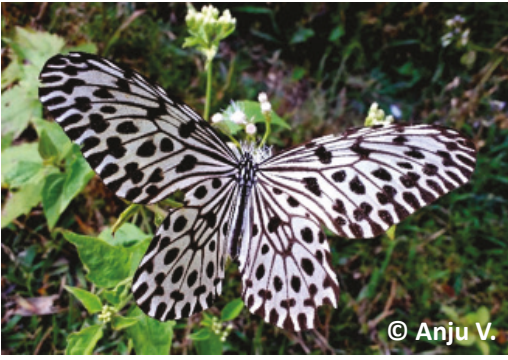

Image 16. Idea malabarica

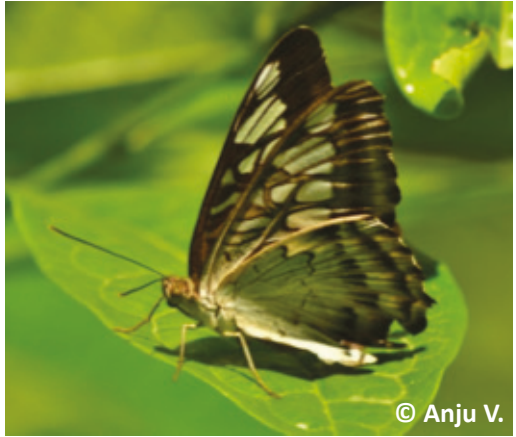

Image 19. Parthenos sylvia

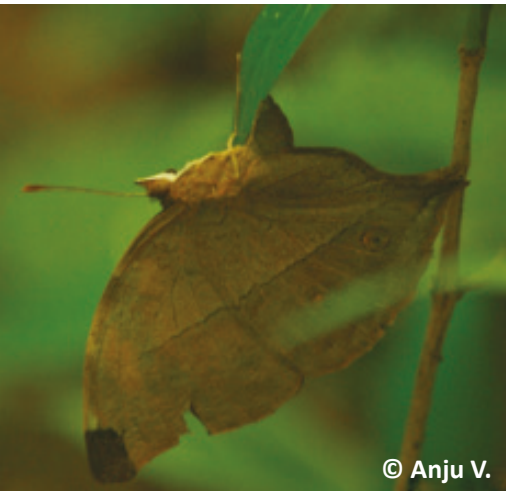

Image 22. Doleschallia bisaltide

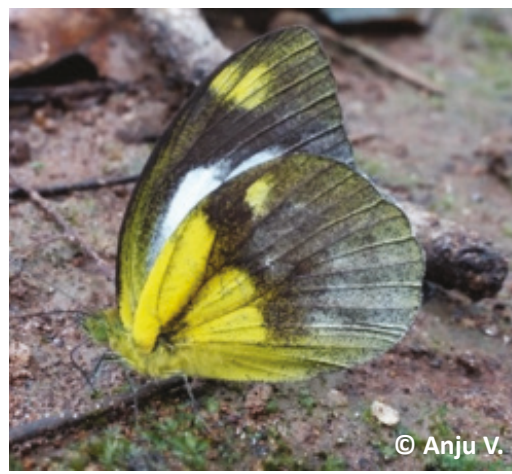

Image 14. Cepora nadina

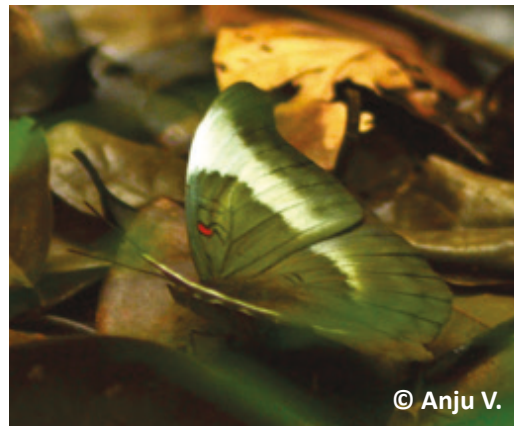

Image 17. Dophla evelina

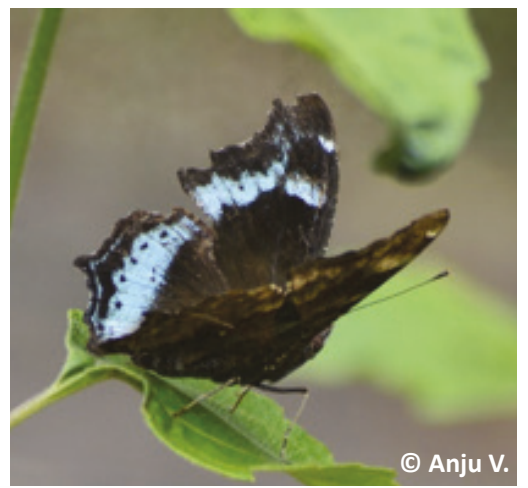

Image 20. Kaniska canace

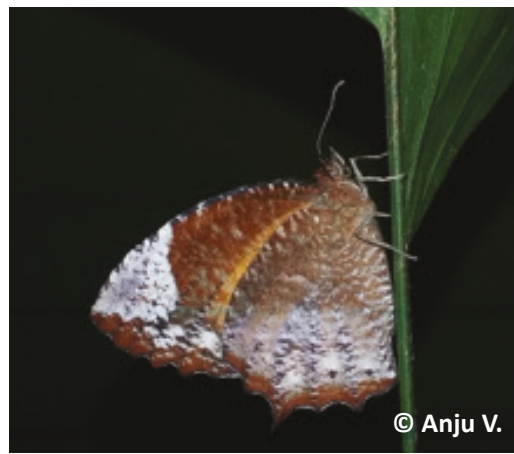

Image 23. Elymnias caudata

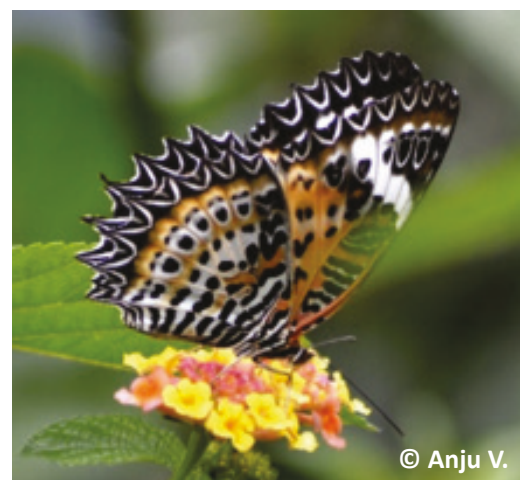

Image 15. Cethosia nietneri

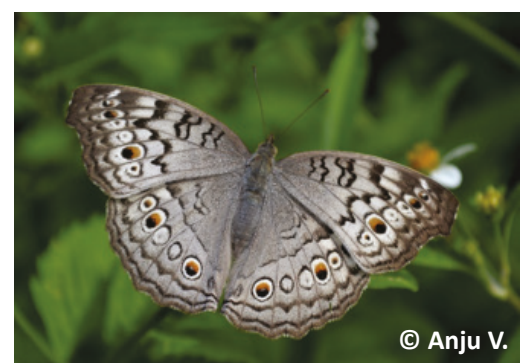

Image 18. Junonia atlites

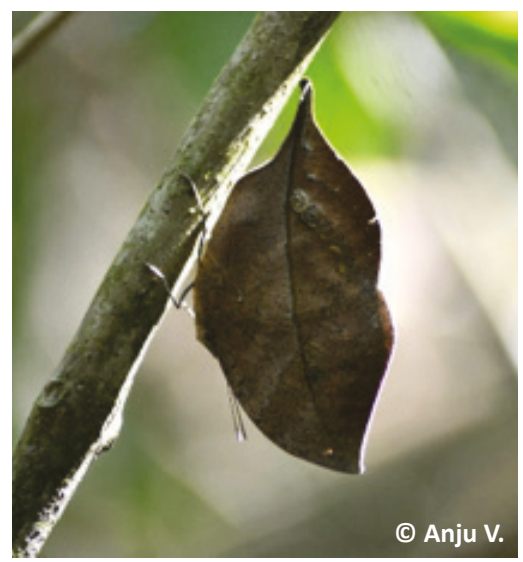

Image 21. Kallima horsfieldii

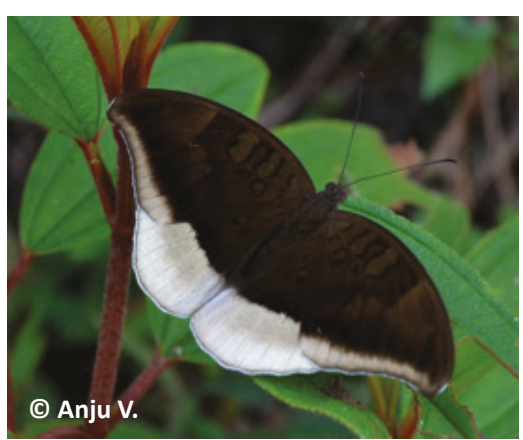

Image 24. Tanaecia lepidea 


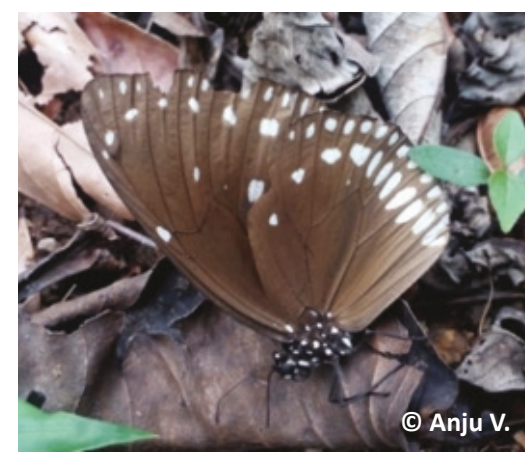

Image 25. Euploea klugii

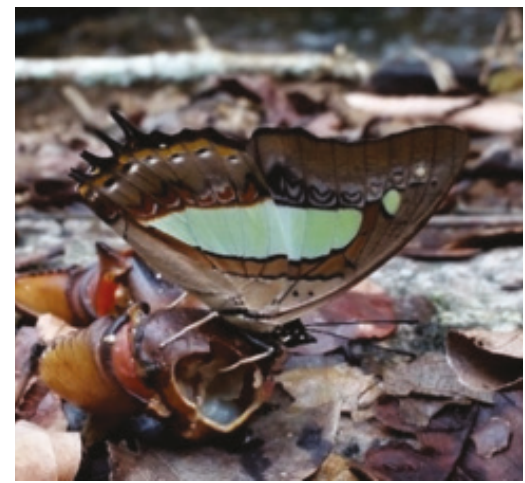

Image 28. Polyura athamas

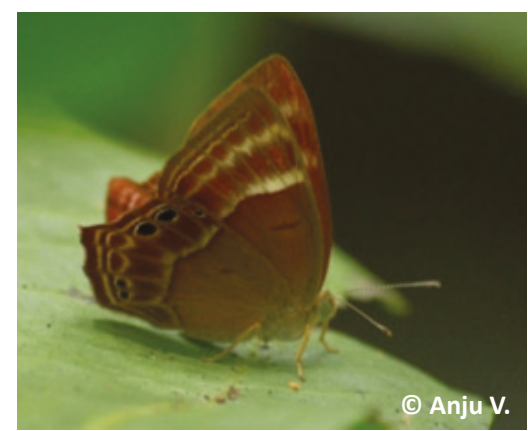

Image 31. Abisara bifasciata

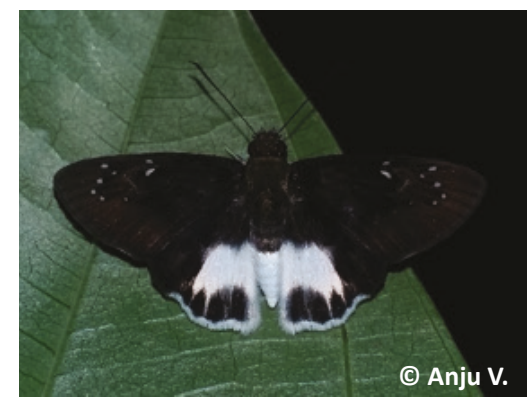

Image 34. Tagiades litigiosa

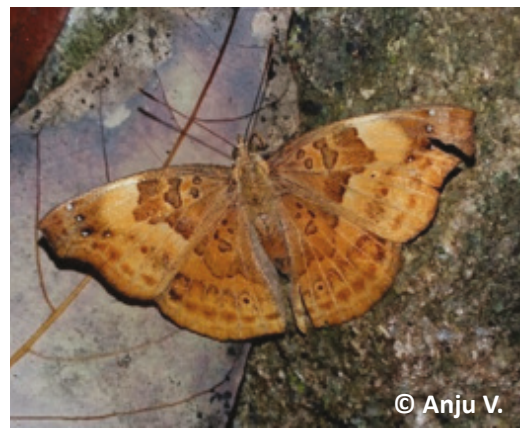

Image 26. Rohana parisatis

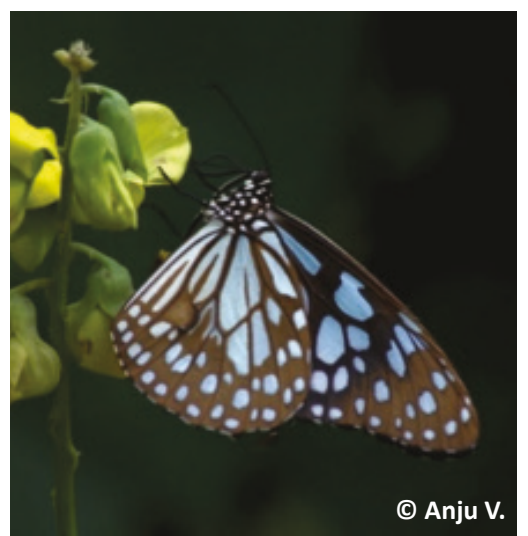

Image 29. Tirumala limniace

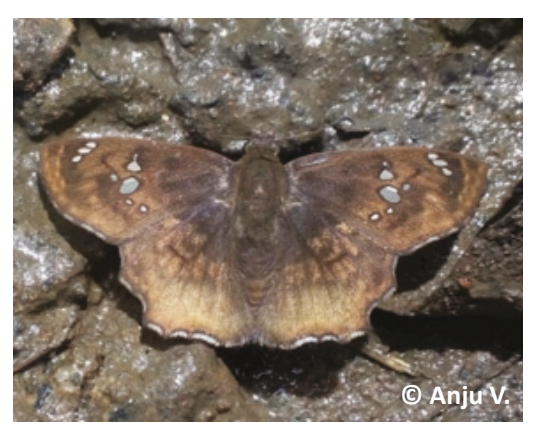

Image 32. Caprona ransonnettii

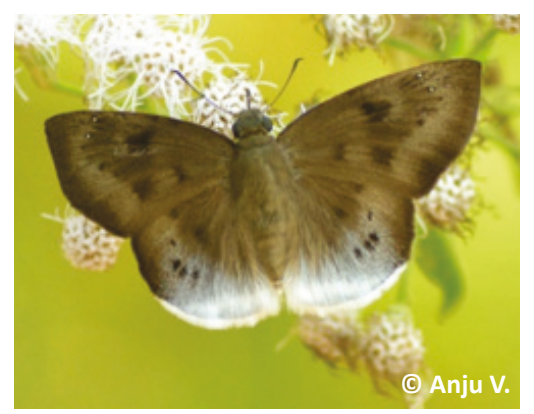

Image 35. Tagiades gana silvia

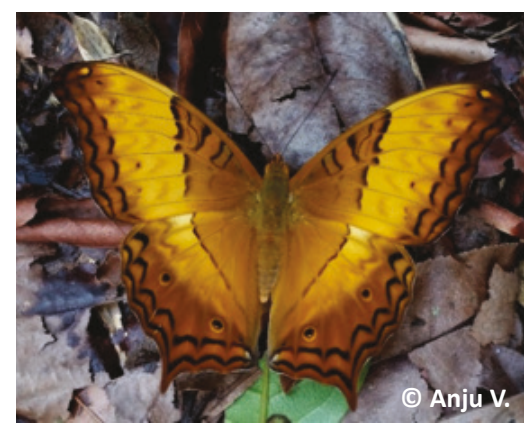

Image 27. Vindula erota

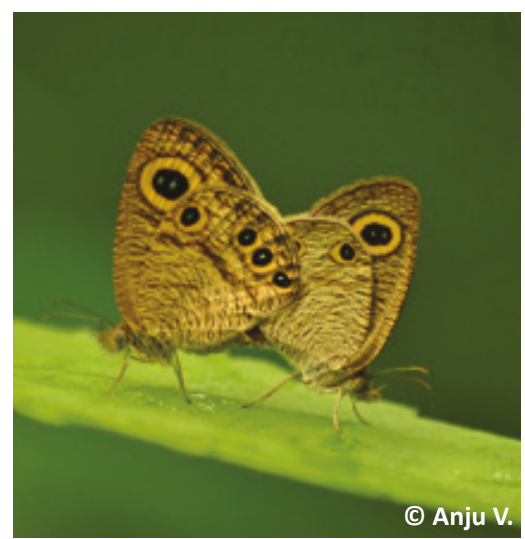

Image 30. Ypthima huebneri

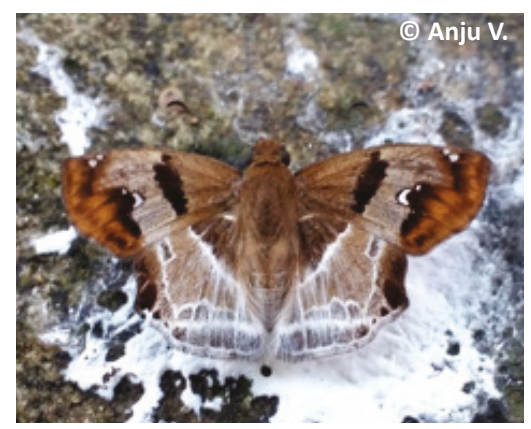

Image 33. Odontoptilum angulata

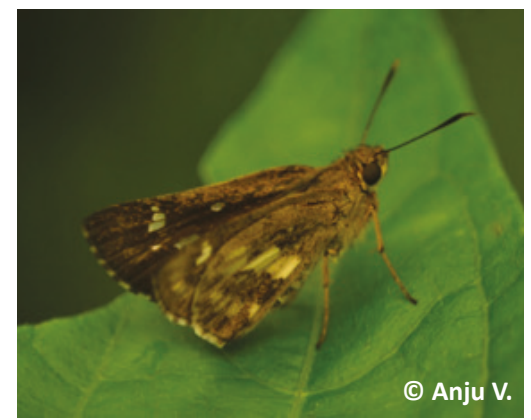

Image 36. Halpe homelea hindu 


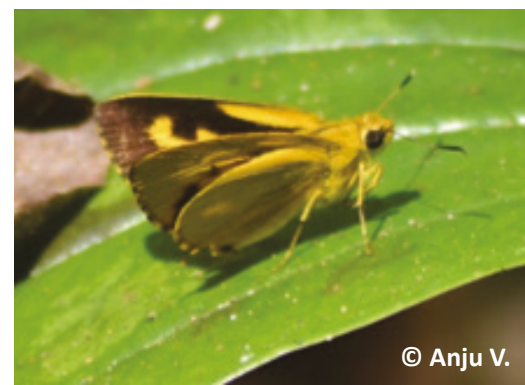

Image 37. Cupitha purreea

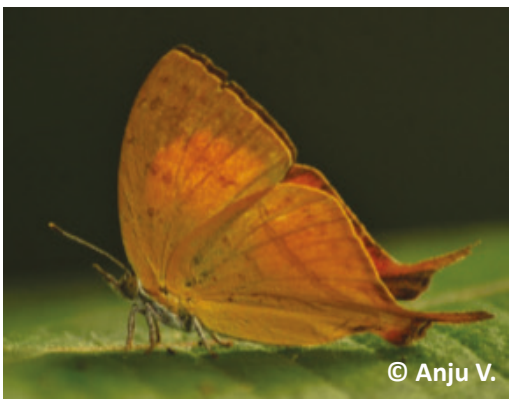

Image 40. Loxura atymnus atymnus

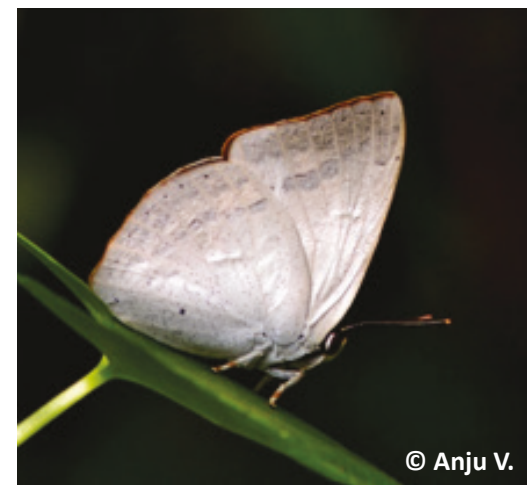

Image 43. Curetis siva

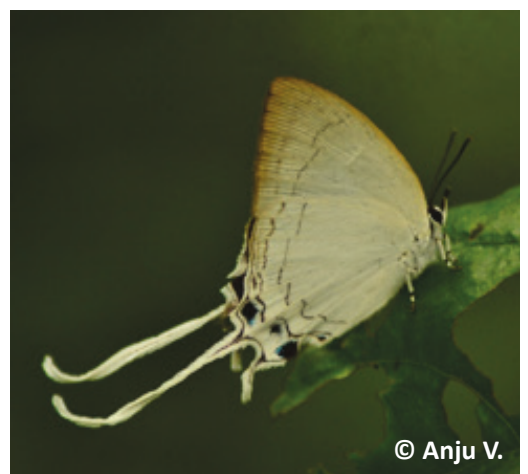

Image 38. Cheritra freja butleri

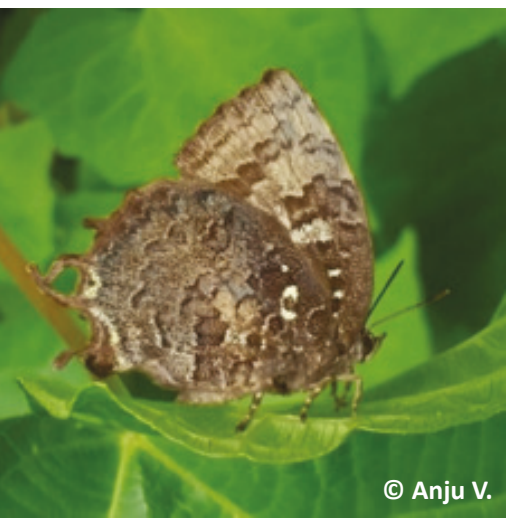

Image 39. Thaduka multicaudata Kanara

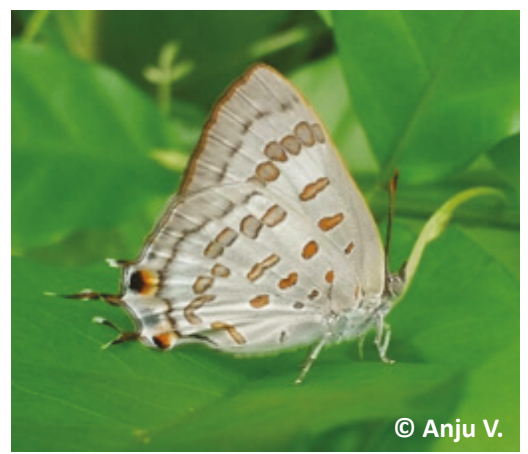

Image 41. Zesius chrysomallus

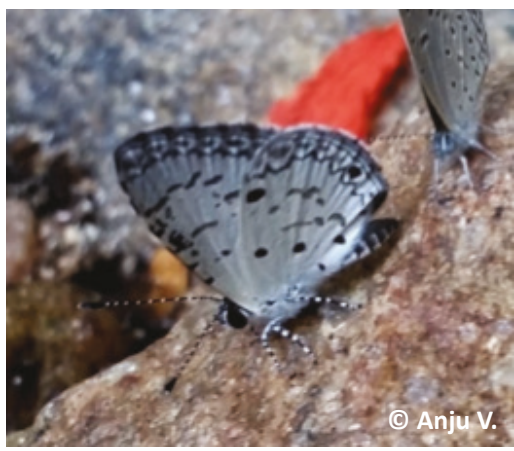

Image 44. Megisba malaya

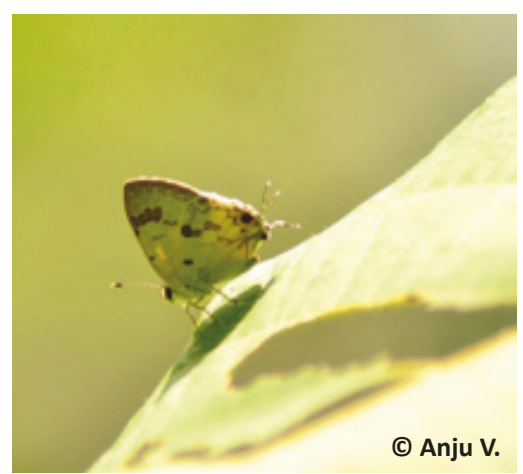

Image 42. Chliaria othona

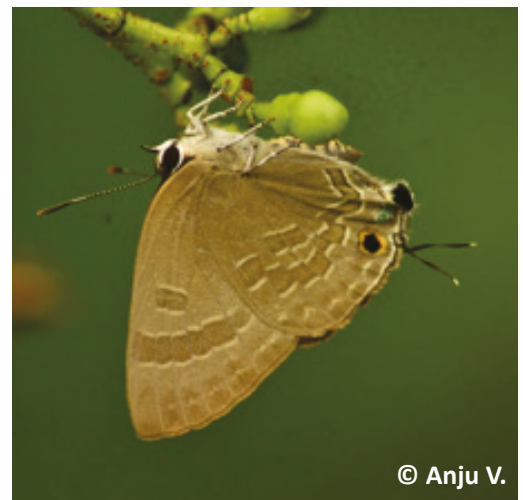

Image 45. Deudorix epijarbas 
The model was highly significant and explained $86.9 \%$ variation in the detection of butterflies. Both abundance and size positively influenced the number of detections. From the standardized partial regression, abundance $\left(b_{1}=0.74\right)$ had the primary influence on the detection of butterflies, followed by size $\left(b_{2}=0.19\right)$ and activity $\left(b_{3}=\right.$ 0.02). Similar species-wise differences in the detection of butterflies were reported in the studies carried out in the United Kingdom (Isaac et al. 2011; Pellet et al. 2012). Further investigation on the detectability of butterflies based on size, colouration, and habitats will help to estimate population size rather than species abundance.

\section{REFERENCES}

Aneesh, K.S, C.K. Adarsh \& P.O. Nameer (2013). Butterflies of Kerala agricultural university (KAU) campus, Thrissur, Kerala, India. Journal of Threatened Taxa 5(9): 4422-4440. https://doi.org/10.11609/ JoTT.02870.4422-40

Bhakre, M. \& H. Ogle (2018). A Guide to the Butterflies of Western Ghats (India) Includes Butterflies of Kerala, Karnataka, Goa, Maharashtra and Gujarat States. $1^{\text {st }}$ Edition. Oxford University Press, Mumbai, 496pp.

Gaonkar, H. (1996). Butterflies of the Western Ghats, India including Sri Lanka - A biodiversity assessment of a threatened mountain system. Centre for Ecological Sciences, Bangalore, 89pp.

George, V.A. (2012). Management plan-Chimmony Wildlife Sanctuary.
Government of Kerala, Forest and wildlife department, New Delhi, $176 p p$.

Gupta, I.J. \& M. Majumdar (2012). Handbook on Diversity in some of the Indian Butterflies (Insecta: Lepidoptera). Zoological Survey of India, Kolkata, viii+324pp.

Hammer, O., D.A.T. Harper \& P.D. Ryan (2001). PAST: Paleontological Statistics software package for education and data analysis, Palaeontologia Electronica 4(1): 9

Isaac, N.J., K.L. Cruickshanks, A.M. Weddle, J.M. Rowcliffe, T.M. Brereton, R.L.H. Dennis, D.M. Shuker \& C.D. Thomas (2011). Distance sampling and challenge of monitoring butterfly populations. Methods in Ecology and Evolution 2: 585-594.

Kehimkar, I. (2016). The Book of Indian Butterflies. $2^{\text {nd }}$ Edition. Bombay Natural History Society, Mumbai, 509pp.

Kunte, K. (2006). Butterflies of Peninsular India. $2^{\text {nd }}$ Edition. Indian Academy of Sciences. Universities Press, Bangalore, xviii+254pp.

Myers, N., R.A. Mittermeier, C.G. Mittermeier, G.A.B. Fonseca \& J. Kent (2000). Biodiversity hotspots for conservation priorities. Nature 403(6772): 853-858.

Palot, M.J., V.C. Balakrishnan, B. Valappil \& G.H. Nair (2015). Butterfly diversity of Aralam Wildlife Sanctuary. Forest Development Agency, Kerala Forest and Wildlife Department, Aralam Wildlife Sanctuary, Kannur.

Pellet, J., J.T. Bried, D. Parietti, A. Gander, P.O. Heer, D. Cherix \& R. Arlettaz (2012). Monitoring butterfly abundance: Beyond pollard walks, PlosOne 7(7): 1-8.

Sreekumar, P.G. \& M. Balakrishnan (2001). Habitat and altitude preferences of butterflies in Aralam Wildlife Sanctuary, Kerala. Tropical Ecology 42(2): 277-281.

Sudheendrakumar, V.V., C.F. Binoy, P.V. Suresh \& G. Mathew (2000). Habitat association of butterflies in Parambikulam Wildlife Sanctuary, Kerala, India. Journal of the Bombay Natural History Society 97(2): 193-201. 



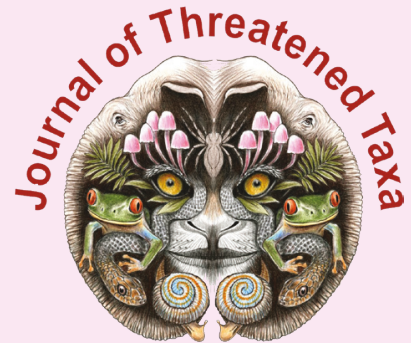

www.threatenedtaxa.org
PLATINUM OPEN ACCESS

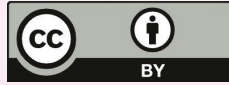

The Journal of Threatened Taxa (JoTT) is dedicated to building evidence for conservation globally by publishing peer-reviewed articles online every month at a reasonably rapid rate at www.threatenedtaxa.org. All articles published in JoTT are registered under Creative Commons Attribution 4.0 International License unless otherwise mentioned. JoTT allows allows unrestricted use, reproduction, and distribution of articles in any medium by providing adequate credit to the author(s) and the source of publication.

\title{
ISSN 0974-7907 (Online) | ISSN 0974-7893 (Print)
}

\author{
March 2021 | Vol. 13 | No. 3 | Pages: 17847-18058 \\ Date of Publication: 26 March 2021 (Online \& Print) \\ DOI: 10.11609/jott.2021.13.3.17847-18058
}

Article

Decline of White-throated Bushchat Saxicola insignis Gray J.E. \& J.R. Gray, 1847 (Aves: Passeriformes: Muscicapidae) in Nepal: implications on its global status

- Hem Sagar Baral, Tek Raj Bhatt, Bed Kumar Dhakal, Dhiraj Chaudhary, Hemanta Kuma Yadav, Laxman Prasad Poudyal, Hathan Chaudhary, Pradeep Raj Joshi, Carol Inskipp \& Rajan Amin, Pp. 17847-17855

\section{Conservation Application}

Relocation of a GPS collared conflict Sloth Bear Melursus ursinus (Mammalia: Carnivora) in Karnataka, Indiat

- Attur Shanmugam Arun, Shanmugavelu Swaminathan, Yogaraj Pannerselvam, Thomas Robert Sharp, Sydney Rae Stephens, Kartick Satyanarayan \& Geeta Seshamani, Pp. 1785617864

\section{Communications}

Not all gone: the rediscovery of Jaguar (Carnivora: Felidae: Panthera onca) and records of threatened monkeys (Primates: Mammalia) in the Magdalena River Valley of Caldas Department in Colombia, a call for their conservation

- Leonardo Mendieta-Giraldo, Sergio Escobar-Lasso, Esteban Grajales-Suaza \& José F. González-Maya, Pp. 17865-17874

First confirmed sightings of Blue Whales Balaenoptera musculus Linnaeus, 1758 (Mammalia: Cetartiodactyla: Balaenopteridae) in the Philippines since the 19th century - Jo Marie Vera Acebes, Joshua Neal Silberg, Timothy John Gardner, Edna Rex Sabater, Angelico Jose Cavada Tiongson, Patricia Dumandan, Diana Maria Margarita Verdote, Christine Louise Emata, Jean Utzurrum \& Arnel Andrew Yaptinchay, Pp. 17875-17888

Parasitic infection in captive wild mammals and birds in Bangabandhu Sheikh Mujib Safari Park, Cox's Bazar, Bangladesh

- M. Najmul Hossain, Anita Rani Dey, Nurjahan Begum \& Thahsin Farjana, Pp. 17889-17894

A rapid assessment of waterbirds and the mangrove status in the Menabe Antimena Protected Area, Madagascar

- Christoph Zöckler, Solofo Ndrina Razanamaheninina \& Matthias Markolf, Pp. 17895-17905

An appraisal of avian species diversity in and around Purulia Town, West Bengal, India - Swastik Mahato, Sudipta Mandal \& Dipanwita Das, Pp. 17906-17917

An annotated checklist of amphibians in and around Dampa Tiger Reserve, Mizoram, India - Ht. Decemson, Sushanto Gouda, Lalbiakzuala, Lalmuansanga, Gospel Zothanmawia Hmar, Mathipi Vabeiryureilai \& H.T. Lalremsanga, Pp. 17918-17929

Redescription of the bug Aschistocoris brevicornis (Heteroptera: Coreidae) and first report on its life history from northern Maharashtra, India

- Digvijay R. Jadhav, Renuka R. Khairnar, Balasaheb V. Sarode, Swapnil S. Boyane \& Hemant V. Ghate, Pp. 17930-17938

A new taxon of Nacaduba Moore, 1881 (Lepidoptera: Lycaenidae: Polyommatini) from Agasthyamalais of the Western Ghats, India

- Kalesh Sadasivan, Baiju Kochunarayanan, Rahul Khot \& S. Ramasamy Kamaya Naicker, Pp. 17939-17949

Does the size of the butterfly enhance detection? Factors influencing butterfly detection in species inventory surveys

- Anju Velayudhan, Ashokkumar Mohanarangan, George Chandy \& S. Biju, Pp. 17950-17962

Dragonflies and damselflies (Insecta: Odonata) of the Kole Wetlands, central Kerala, India - A. Vivek Chandran, Subin K. Jose \& Sujith V. Gopalan, Pp. 17963-17971

Distribution and diversity of climbing species in Papum Pare District of Arunachal Pradesh, India

- Soyala Kashung, Padma Raj Gajurel \& Binay Singh, Pp. 17972-17983
Short Communications

Occurrence of mammalian small carnivores in Kalakad-Mundanthurai Tiger Reserve, Western Ghats, India

- A. Venkatesh, N. Sridharan, S. Agnes Jeya Packiavathi \& K. Muthamizh Selvan, Pp. 1798417989

Changed avian assemblage of Savitribai Phule Pune University campus in last four decades - Kiran Choudaj \& Varsha Wankhade, Pp. 17990-17998

Sandracottus vijayakumari (Coleoptera: Dytiscidae), a new aquatic beetle species from landslide hit area of Nelliyampathy Forest Range, Western Ghats, Kerala, India - P.P. Anand, P.P. Ashiq, M. Smitha, M. Adhithya, T. Tibin \& V. Suresh, Pp. 17999-18003

The genus Basiria Siddiqi, 1959 (Nematoda: Tylenchidae) from Dezful region, Iran - Manouchehr Hosseinvand, Ali Eskandari \& Reza Ghaderi, Pp. 18004-18010

A new species of braconid wasp Meteorus Haliday (Hymenoptera: Braconidae: Meteorinae) from India

- Zaheer Ahmed, Altaf Hussain Mir \& Mohammad Shamim, Pp. 18011-18014

Addition of four woodlice species (Crustacea: Isopoda) to the checklist of Iranian Oniscidea - Yaser Bakhshi, Saber Sadeghi, Hamid Darvishnia \& Meysam Dashan, Pp. 18015-18019

Catalogue of selected insect groups of Lalwan Community Reserve and Ranjit Sagar Conservation Reserve, Punjab, India

- Amar Paul Singh, Agni Chandra, Virendra Prasad Uniyal \& Bhupendra Singh Adhikari, Pp. 18020-18029

Potential phytophagous insects of Pteridium revolutum (Blume) Nakai, an invasive fern - M.S. Arjun \& S. Gopakumar, Pp. 18030-18034

Notes

Freshwater medusae Limnocnida indica Annandale, 1911 in the Cauvery Wildlife Sanctuary, Dubare Reserve Forest and Shivanasamudram in Karnataka, India, with a commentary note on the exotic Craspedacusta sowerbii Lankester, 1880

- Naren Sreenivasan \& Joshua Barton, Pp. 18035-18038

Actinor radians (Moore, 1878) (Hesperiidae: Hesperiinae: Aeromachini): addition to the butterfly fauna of Haryana, India

- Bitupan Boruah, Rajesh Chahal \& Abhijit Das, Pp. 18039-18041

Rediscovery of the rare Desert Grizzled Skipper Spialia doris evanida Butler, 1880 (Hesperiidae: Pyrginae) from the Thar Desert, Rajasthan, India

- Shyam Sundar Meena, Anil Tripathi, Vijay Kumar Koli \& M. Akram Awan, Pp. 18042-18044

Habitat association and hybridization in woodbrowns (Lethe nicetas, L. sidonis, \& L. dakwania) (Lepidoptera: Nymphalidae: Satyrinae) in Kedarnath Musk Deer Reserve, western Himalaya

- Arun Pratap Singh \& Tribhuwan Singh, Pp. 18045-18049

Begonia flaviflora Hara (Begoniaceae): a new record to the flora of Bhutan - Phub Gyeltshen, Sherab Jamtsho, Sangay Wangchuk \& Dhan Bahadur Subba, Pp. 1805018053

Revisiting the taxonomy of Strobilanthes lawsonii and S. pushpangadanii (Acanthaceae), two endemic taxa of Western Ghats, India

- Blessy Cherian, K.M. Prabhukumar, R. Jagadeesan, V.V. Naveen Kumar \& Indira Balachandran, Pp. 18054-18058

\section{Member}

\section{Publisher \& Host}

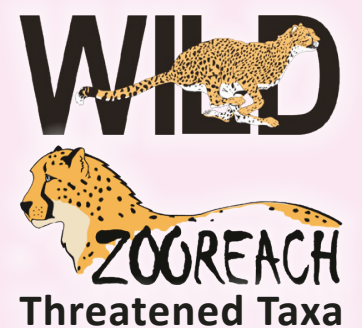

